\title{
Foodborne spread of hepatitis A: Recent studies on virus survival, transfer and inactivation
}

\author{
Syed A Sattar $\mathrm{PhD}^{1}$, Jason Tetro BSc${ }^{1}$, Sabah Bidawid $\mathrm{MSc}^{2}$, Jeff Farber $\mathrm{PhD}^{2}$
}

\begin{abstract}
SA Sattar, J Tetro, S Bidawid, J Farber. Foodborne spread of hepatitis A: Recent studies on virus survival, transfer and inactivation. Can J Infect Dis 2000;11(3):159-163.

Hepatitis A virus (HAV) is responsible for considerable morbidity and economic losses worldwide, and is the only reportable, foodborne viral pathogen in Canada. Outbreaks caused by it occur more frequently in settings such as hospitals, daycare centres, schools, and in association with foods and food service establishments. In recent years, the incidence of hepatitis A has increased in Canada. Many factors, including changing lifestyles and demographics, faster and more frequent travel, and enhanced importation of foods from hepatitis A-endemic regions, may be behind this increase. Despite its increasing significance as a human pathogen, not much was known until recently about the survival and inactivation of HAV, and even less was understood about the effectiveness of measures to prevent and control its foodborne spread. Studies conducted in the past decade have shown that HAV can survive for several hours on human hands and for several days on environmental surfaces indoors. The virus can also retain its infectivity for several days on fruits and vegetables which are often consumed raw, and such imported items have already been incriminated in disease outbreaks. Casual contact between contaminated hands and clean food items can readily lead to a transfer of as much as $10 \%$ of the infectious virus. HAV is also relatively resistant to inactivation by heat, gamma irradiation and chemical germicides. In view of these findings, better approaches to prevent the contamination of foods with HAV and more effective methods for its inactivation in foods, on environmental surfaces and on the hands of food handlers are needed.
\end{abstract}

Key Words: Foodborne diseases; Food handlers; Hepatitis A; Hepatitis A virus; Virus inactivation; Virus survival; Virus transfer

Transmission de l'hépatite A par la nourriture : études récentes sur la survie, le transfert et l'inactivation du virus

RÉSUMÉ : Le virus de l'hépatite $\mathrm{A}(\mathrm{HAV})$ est lié à une importante morbidité et à des pertes économiques considérables à l'échelle mondiale, au Canada, c'est le seul pathogène viral transmis par la nourriture à déclaration obligatoire. Des flambées d'hépatite A surviennent plus souvent dans des endroits comme les hôpitaux, les garderies, les écoles, et en association avec des aliments et des entreprises de services alimentaires. Ces dernières années, l'incidence de l'hépatite A a augmenté au Canada. De nombreux facteurs, y compris les changements de mode de vie et la démographie, les voyages plus fréquents et plus rapides, et une plus grande importation d'aliments en provenance de régions endémiques pour l'hépatite A, pourraient expliquer cette augmentation. Malgré son importance croissante comme pathogène humain, on savait peu de choses jusqu'à récemment sur la survie et l'inactivation du HAV, et encore moins sur l'efficacité des mesures pour prévenir et contrôler sa transmission par la nourriture. Des études menées ces dix dernières années ont démontré que le HAV peut survivre pendant plusieurs heures sur des mains humaines et pendant plusieurs jours sur des surfaces environnementales intérieures. De plus, le virus peut conserver son infectivité pendant plusieurs jours sur les fruits et les légumes qui sont souvent consommés crus, et ce type de denrées importées ont déjà été incriminés dans les flambées d'hépatite A. Un contact accidentel entre des mains contaminées et des denrées alimentaires propres peut facilement entraîner un transfert d'au moins 10 \% des virus infectieux. Le HAV est aussi relativement résistant à l'inactivation par la chaleur, l'irradiation gamma et aux germicides chimiques. À la vue de ces résultats, il est nécessaire de développer de nouvelles stratégies pour prévenir la contamination des aliments par le HAV et des méthodes plus efficaces pour son inactivation dans les aliments, sur les surfaces environnementales et sur les mains des travailleurs de l'alimentation.

\footnotetext{
Presented at the BIOP '99 Symposium, Ryerson Polytechnic University, Toronto, Ontario February 25, 1999

${ }^{1}$ Centre for Research on Environmental Microbiology, Faculty of Medicine, University of Ottawa; ${ }^{2}$ Food Directorate, Health Canada, Ottawa, Ontario

Correspondence and reprints: Dr Syed A Sattar, Centre for Research on Environmental Microbiology, Faculty of Medicine, University of Ottawa, 451 Smyth Road, Ottawa, Ontario K1H 8M5. Telephone 613-562-5800 ext 8314, fax 613-562-5452, e-mail ssattar@uottawa.ca
} 
$\mathrm{H}$ epatitis A virus (HAV), the causative agent of hepatitis A, is a major public health problem (1), and it causes considerable morbidity and economic losses on a global basis (2). HAV is the fifth most commonly reported infectious disease in the United States, and it ranks sixth among the top 10 foodborne pathogens (3). Hepatitis A is also the only reportable foodborne viral disease in North America (4) and is the most frequently reported vaccine-preventable disease in the United States (5). It is on the list of Severe Hazards in Appendix V of the United States Food and Drug Administration (4).

$\mathrm{HAV}$, a member of the genus Hepatovirus in the family Picornaviridae $(6,7)$, is shed in the feces of infected individuals. The virus is transmitted primarily through the ingestion of fecally contaminated material (8). Only one serotype of HAV is known and infection with the virus gives long lasting immunity. Virus excretion in feces begins well before the appearance of clinical signs and symptoms, and continues for several days thereafter. Many individuals, particularly children, may become infected with the virus without becoming sick. Such 'silent' disseminators of the virus may pass the virus on to others around them. These factors make it virtually impossible to identify and isolate infected persons before they begin to excrete the virus. Hence, emphasis on good personal and environmental hygiene is essential.

In recent years, the incidence of hepatitis A has increased in Canada (9). Among the reasons for this increase are increased travel to and from areas with a higher endemicity of the disease; increases in high risk sexual practices and the use of illicit drugs; more and more children in daycare, with a correspondingly greater opportunity for HAV spread to others in the family and the community; and increasing importations of fresh fruits and vegetables from regions with less stringent environmental controls. Such food items have been implicated in outbreaks of hepatitis A in the United States (10).

This brief review summarizes the findings of our recent studies on the ability of HAV to survive on hands and non-porous environmental surfaces, as well as in and on several items of food, and the potential utility of heat and gamma irradiation in the inactivation of HAV on experimentally contaminated dairy products and food items (produce), which are often consumed raw or minimally processed. It also highlights the current knowledge about the transfer of HAV from contaminated fingerpads to clean surfaces and objects during casual contact. Recommendations for future research are also made.

\section{FOODBORNE SPREAD OF HAV}

Types of foods implicated in the transmission of HAV include shellfish, salads, sandwiches, vegetables, fruits, reconstituted frozen orange juice, ice cream, cheese, rice pudding, iced cake, custard, milk, bread, cookies and other raw or undercooked foods (4). Contamination of foods with HAV can occur in several different ways: fruits and vegetables cultivated in and/or irrigated with fecally contaminated materials; shellfish grown in and harvested from fecally polluted waters (4); processing and preparation of food in fecally soiled equipment; and handling of ready-to-eat items of food by infected individuals with poor personal hygiene (11). Food establish-
TABLE 1

Survival of hepatitis A virus on the hands of adult volunteers

\begin{tabular}{lccccc}
\hline & \multicolumn{5}{c}{ Volunteer } \\
& A & B & C & D & E \\
\hline Half-life (h) & 6.10 & 7.20 & 6.10 & 7.70 & 5.50 \\
Ki value* & 0.0019 & 0.0016 & 0.0019 & 0.0015 & 0.0021 \\
\hline
\end{tabular}

*Rate of loss in virus infectivity as $\log _{10}$ per minute; there was no statistically significant difference in the Ki values for the five volunteers. Adapted from reference 14

ments with poor sanitary conditions and inadequate waste disposal systems, along with unsatisfactory manufacturing practices, may also contribute to food contamination.

\section{SURVIVAL AND TRANSFER OF HAV}

HAV can readily survive freezing, persist in fresh or salt water for up to 12 months (12) and can retain its infectivity for a few days to weeks in dried feces (13). It is also quite resistant to many environmental conditions as well as physical and chemical agents $(14,15)$.

Virus survival on animate and inanimate surfaces: HAV can survive for several hours on human hands (14) and several days on environmental surfaces indoors (16). The ability of the virus to survive on hands was studied by suspending a laboratory-adapted strain (HM-175) of the virus in feces, placing it on the fingerpads of adult volunteers and recovering the virus over a period of several hours. The eluates were titrated for infectious virus using a plaque assay method, and the rate of decay in virus infectivity was determined. Its half-life ranged from $5.50 \mathrm{~h}$ to $7.70 \mathrm{~h}$ (Table 1 ). This suggests that the virus has the potential to retain its infectivity on hands for the better part of a work shift if food handlers or caregivers fail to decontaminate them properly and frequently. It is also worth noting that, in comparative studies, HAV has been found to survive on hands longer than several other human pathogenic viruses and bacteria (17).

HAV can survive on nonporous environmental surfaces even better than on human skin over a wide range of ambient temperatures and relative humidities (RHs). This was tested by placing fecally suspended virus on stainless steel disks and eluting it over a period of several days to measure its infectivity. The findings of these experiments are presented in Table 2 (16). When held at the refrigeration temperature of $5^{\circ} \mathrm{C}, \mathrm{HAV}$ had a half-life of at least $103 \mathrm{~h}$ (more than four days), irrespective of RH. At $20^{\circ} \mathrm{C}$, its half-life was the longest (nearly 7.8 days) when the RH was low and shortest (a little over two days) at the highest $\mathrm{RH}$ level. Even at $35^{\circ} \mathrm{C}$, HAV showed a half-life of $65 \mathrm{~h}$ (2.7 days) at the low RH. It did not survive well when held at $35^{\circ} \mathrm{C}$ with an $\mathrm{RH}$ of $95 \% \pm 5 \%$. In comparison with HAV, poliovirus type 1 (Sabin), a prototypical picornavirus, showed poor survival under the same test conditions.

In view of the increasing use of ready-to-eat vegetables sold in modified atmosphere packaging (MAP), Bidawid et al (18) recently studied the survival of HAV on lettuce in MAP stored at room temperature and $4^{\circ} \mathrm{C}$. The results showed that the survival of $\mathrm{HAV}$ at $4^{\circ} \mathrm{C}$ was about the same in MAP and under ordinary conditions of packaging, and that virus survival was 
TABLE 2

The half-lives in hours (Ki values)* of hepatitis A virus (HM-175) and poliovirus type 1 (Sabin) on nonporous environmental surfaces under various levels of air temperature and relative humidity

\begin{tabular}{|c|c|c|c|c|c|}
\hline \multirow[b]{2}{*}{ Virus tested } & \multirow[b]{2}{*}{ Holding temperature $\left({ }^{\circ} \mathrm{C}\right)$} & \multicolumn{4}{|c|}{$\%$ Relative humidity } \\
\hline & & $25 \pm 5$ & $55 \pm 5$ & $80 \pm 5$ & $95 \pm 5$ \\
\hline \multirow[t]{3}{*}{ Hepatitis A } & 5 & $169(0.0041)$ & $151(0.0046)$ & $123(0.0056)$ & $103(0.0067)$ \\
\hline & 20 & $187(0.0037)$ & $128(0.0054)$ & $71(0.0097)$ & $51(0.0136)$ \\
\hline & 35 & $65(0.0106)$ & $50(0.0138)$ & $21(0.0329)$ & $2(0.0984)$ \\
\hline Poliovirus type 1 & 20 & $2(0.3928)$ & NT & NT & $7(0.0984)$ \\
\hline
\end{tabular}

*Rate of loss in virus infectivity as $\log _{10}$ per hour; NT Not tested. Adapted from reference 16

slightly better in MAP containing higher carbon dioxide levels when the contaminated lettuce was stored at room temperature.

While further studies are needed to corroborate and extend these findings, the enhanced survival of HAV in material in MAP stored at room temperature may be due to the inhibition of ethylene by carbon dioxide, resulting in a reduction in the physiological spoilage of vegetables, such as lettuce, and possibly less toxic effects on the virus. It is possible that MAP might have an inhibitory effect on virus replication within host cells. Previous studies (19) have shown that indigenous microflora in the water environment, for example, are deleterious to the survival of enteric viruses. These findings also reinforce the importance of avoiding the contamination of food items before their packaging in MAP.

Virus transfer between contaminated and clean surfaces: HAV can enter into foods after they have been harvested or cooked by their subsequent contact with fecally contaminated hands or environmental surfaces. Because this is a crucial issue in understanding the genesis of many foodborne outbreaks of hepatitis A, as well as for risk assessment and institution of proper environmental control measures, the authors have attempted to address this aspect through a quantitative experimental approach. Each donor surface was contaminated with fecally suspended HAV, and the inoculum allowed to dry for varying lengths under ambient conditions. The donor surface was then brought in contact with a clean recipient surface with the same pressure, friction and duration of contact as would occur in normal work or domestic settings, and the amount of infectious virus transfer was measured (14).

The data summarized in Table 3 show that not only does virus transfer occur with a $10 \mathrm{~s}$ casual contact between contaminated and clean surfaces (pressure $0.2 \mathrm{~kg} / \mathrm{cm}^{2}$ ), but also that the age of the inoculum on the donor surface makes a difference in the amount of virus transferred. When the level of pressure was increased to $1 \mathrm{~kg} / \mathrm{cm}^{2}$ and/or friction was applied during contact, the amount of infectious virus transferred went up by two- to threefold (14). Whereas virus transfer was not attempted while the inoculum was still wet, it would be expected to be much greater, irrespective of the nature of the donor and recipient surfaces involved.

More recently, the authors also studied the transfer of HAV from hands to foods. This was performed by bringing the HAVcontaining dried inoculum in contact $\left(0.2 \mathrm{~kg} / \mathrm{cm}^{2}\right.$, without any friction) with experimentally contaminated fingerpads of adult volunteers with clean pieces of lettuce for $10 \mathrm{~s}$ (20). This resulted in the transfer of nearly $10 \%$ of the infectious virus.
TABLE 3

Transfer of infectious hepatitis A virus between contaminated and clean surfaces

\begin{tabular}{|c|c|c|c|c|c|}
\hline $\begin{array}{l}\text { Transfer } \\
\text { from }\end{array}$ & $\begin{array}{c}\text { Transfer } \\
\text { to }\end{array}$ & $\begin{array}{c}\text { PFU on } \\
\text { donor } \\
\text { surface } \\
\text { at } \\
0 \mathrm{~min} \\
\end{array}$ & $\begin{array}{l}\text { Drying } \\
\text { time on } \\
\text { donor } \\
\text { surface } \\
\text { (mins) }\end{array}$ & PFU transferred & $\begin{array}{c}\% \\
\text { Trans- } \\
\text { ferred }\end{array}$ \\
\hline \multirow[t]{5}{*}{ Metal disk } & $\begin{array}{l}\text { Finger- } \\
\text { pad }\end{array}$ & 10,795 & 20 & 2667 & 24.7 \\
\hline & & & 60 & 1277 & 11.8 \\
\hline & & & 120 & 575 & 5.3 \\
\hline & & & 180 & 233 & 2.16 \\
\hline & & & 240 & 0 & 0 \\
\hline \multirow[t]{5}{*}{ Fingerpad } & $\begin{array}{c}\text { Metal } \\
\text { disk }\end{array}$ & 12,275 & 20 & 3484 & 28.4 \\
\hline & & & 60 & 2092 & 17.0 \\
\hline & & & 120 & 908 & 7.4 \\
\hline & & & 180 & 158 & 1.3 \\
\hline & & & 240 & 50 & 0.4 \\
\hline \multirow[t]{5}{*}{ Fingerpad } & $\begin{array}{l}\text { Finger- } \\
\text { pad }\end{array}$ & 10,433 & 20 & 2800 & 27.0 \\
\hline & & & 60 & 1833 & 17.6 \\
\hline & & & 120 & 933 & 8.9 \\
\hline & & & 180 & 167 & 1.6 \\
\hline & & & 240 & 17 & 0.2 \\
\hline
\end{tabular}

PFU Plaque forming units. Adapted from reference 14

As far as the authors are aware, these data are the first quantitative assessment of HAV transfer and the relationship between pressure and friction during the contact, and should contribute greatly to creating proper environmental control strategies and educating food handlers of the need for avoiding cross-contamination of foods. These findings also reinforce the fact that handwashing alone may not be sufficient to interrupt the spread of foodborne HAV without regular and proper cleaning and decontamination of surfaces and objects that may come in contact with foods frequently.

\section{HAV INACTIVATION BY HEAT}

Heat is the most effective measure in the inactivation of HAV $(21,22)$. Complete inactivation of HAV in the meat of shellfish can be achieved after heating (steaming) shellfish to an internal temperature of $85^{\circ} \mathrm{C}$ to $90^{\circ} \mathrm{C}$ for $1.5 \mathrm{mins}(23)$.

The authors recently tested the effect of fat content on the heat resistance of HAV in skim milk (1\%), homogenized milk ( $3.5 \%$ fat) and table cream (18\% fat) (24). The data in Table 4 
TABLE 4

Time (mins) required for various levels of $\log _{10}$ in the infectivity of hepatitis A virus when dairy products with differing fat levels are heated

\begin{tabular}{lrrrrrrr}
\hline $\begin{array}{l}\text { Dairy product } \\
\text { (fat content) }\end{array}$ & \multicolumn{7}{c}{ Temperature $\left({ }^{\circ} \mathbf{C}\right)$} \\
\hline Skim milk (1\%) & & 69 & 71 & 73 & 75 & 80 & 85 \\
$1 \log _{10}$ reduction & 2.6 & 0.7 & 0.15 & 0.16 & 0.13 & & \\
$4 \log _{10}$ reduction & 33.8 & 15.6 & 6.5 & 5.7 & 0.8 & & \\
$5 \log _{10}$ reduction & & & & & & .68 & .5 \\
Homogenized milk (3.5\%) & & & & & & \\
$1 \log _{10}$ reduction & 6.2 & 0.8 & 0.18 & 0.17 & 0.15 & & \\
$4 \log _{10}$ reduction & 32.6 & 19.0 & 8.3 & 5.9 & 2.8 & & \\
$5 \log _{10}$ reduction & & & & & & 0.68 & 0.5 \\
Table cream (18\%) & & & & & & & \\
$1 \log _{10}$ reduction & 7.3 & 1.1 & 0.52 & 0.36 & 0.26 & & \\
$4 \log _{10}$ reduction & 36.9 & 21.8 & 12.7 & 9.3 & 8.2 & & \\
$5 \log _{10}$ reduction & & & & & & 1.24 & .5 \\
\hline
\end{tabular}

Adapted from reference 24

show that routine pasteurization temperatures are not adequate to inactivate HAV in these dairy products. Furthermore, increasing the fat content appears to play a protective role, and thus can contribute to increased heat stability of the virus in such products.

\section{GAMMA IRRADIATION FOR HAV INACTIVATION ON LETTUCE AND STRAWBERRIES}

The potential of gamma irradiation to inactivate HAV on experimentally contaminated samples of lettuce and strawberries has also been investigated by the authors (25). Log linear and logistical models were used to analyze the data. Using log-linear analysis, D values (the radiation dose needed to reduce HAV infectivity by one $\log _{10}$ ) of $2.72 \pm 0.05 \mathrm{kGy}$ and $2.97 \pm 0.18 \mathrm{kGy}$ were obtained for lettuce and strawberries, respectively. Extrapolation of the data from the nonthreshold model suggested that irradiation doses of $8.20 \pm 0.33 \mathrm{kGy}$ and $9.12 \pm 0.66 \mathrm{kGy}$ would be required to cause a $3 \log _{10}$ reduction in HAV on lettuce and strawberries, respectively. There was no noticeable deterioration in the texture or appearance of either the lettuce or the strawberries throughout the process of irradiation, even at the higher dose of $10 \mathrm{kGy}$.

\section{RESEARCH NEEDS}

We have learned much in recent years about HAV and its behaviour in the environment, and this newly accumulated knowledge has further reinforced the fact that this virus is more resistant than many others to environmental factors and chemical germicides. It also surpasses a number of food pathogens in its ability to survive on human and environmental surfaces. This combination of higher resistance to chemical germicides and better stability in the environment confer on the virus an unusually strong potential to spread via foods. The following are suggested research needs to provide better answers to further reduce the threat of HAV transmission through foods.
More effective and safer formulations are needed to inactivate the virus on hands as well as on environmental surfaces. Products that can readily inactivate HAV are generally unsuitable for use by food handlers and for application on food contact surfaces.

Fruit and vegetable rinses for use in commercial and domestic settings are gaining in popularity. While they may work well against bacterial pathogens, the limited data currently available suggest that they are much less effective against HAV (26). Therefore, further research is required to develop formulations that are effective against HAV as well.

More rapid and sensitive methods are needed to detect HAV in various types of foods. Knowing the difficulties in the culture of field strains of HAV and the generally low levels of infectious virus present in incriminated food samples, it is highly unlikely that any breakthroughs in the detection of infectious HAV in foods will be seen soon. However, improvements in molecular methods alone or in combination with immunological approaches may allow the detection of HAV RNA, which could at least indicate the presence of HAV in foods.

Increasing numbers of people are now receiving vaccination against hepatitis A. It would be valuable to investigate if such vaccination in any way reduces the ability of HAV to survive on the hands of vaccinated individuals. If such is the case, it will prove to be an added bonus for vaccinated food handlers.

Innovative approaches are urgently needed to encourage better compliance with handwashing, particularly in people who harvest, prepare and serve foods.

\section{CONCLUSIONS}

The experimental evidence generated in the past decade clearly shows the ability of HAV to survive well in the indoor environment, on human hands, as well as in and on many items of food (4). It has also been demonstrated that the transfer of the infectious virus can readily occur on casual contact between hands and environmental surfaces (14), and that HAV is relatively resistant to inactivation by chemical germicides and other chemical and physical agents $(15,27)$. In view of all these considerations, it is considered ever more urgent to apprise all those connected with the food industry of the importance of environmental and other control measures based on the most recent scientific data available on HAV.

The advent of active immunization against hepatitis $A$ is an important advance in public health because its proper and sustained use could see the eventual eradication of this disease. The injectable nature of the available vaccines makes them somewhat expensive and difficult to administer. But the vaccination of targeted individuals, particularly those who handle food and work in daycare and healthcare settings, should see a noticeable reduction in the number of cases of hepatitis $A$ in North America and other industrialized parts of the world. 
No amount of published information on hepatitis A and its causative agent is likely to reduce the threat of spread of the disease through foods unless it reaches, in an understandable and meaningful format, all those who work in the food industry. This is particularly important for workers who actually handle foods at various stages of its production and sale on a regular basis. A detailed guide for the control and prevention of HAV spread in food production and service establishments has recently been formulated (28).

ACKNOWLEDGEMENTS: The authors thank John Mbithi for much of the work on virus survival and transfer summarized in this review. We are also grateful to the Stanier Society for the invitation to present our research findings at the symposium held on February 25, 1999 at Ryerson Polytechnic University, Toronto, Ontario.

\section{REFERENCES}

1. Koff RS. Hepatitis A. Lancet 1998;351:1643-9.

2. World Health Organization. Public health control of hepatitis A: Memorandum from a WHO meeting. Bull WHO 1995; 73:15-20.

3. Centers for Disease Control and Prevention. Ten leading nationally notifiable infectious diseases - United States, 1995. MMWR Morb Mortal Wkly Rep 1996;45:883-4.

4. Cliver DO. Virus transmission via food. World Health Stat Q 1997;50:90-101.

5. Bell BP, Shapiro CN, Alter MJ, et al. The diverse patterns of hepatitis A epidemiology in the United States - implications for vaccination strategies. J Infect Dis 1998;178:1579-84

6. Feinstone SM. Hepatitis A: epidemiology and prevention. Eur J Gastroenterol Hepatol 1996;8:300-5.

7. Melnick JL. History and epidemiology of hepatitis A virus. J Infect Dis 1995;171(Suppl 1):S2-8.

8. Lemon SM. Type A viral hepatitis: epidemiology, diagnosis, and prevention. Clin Chem 1997;43:1494-9.

9. Health Canada. Laboratory evidence of human viral and selected non-viral infection in Canada - 1989 to 1996. Can Commun Dis Rep 1998; $1: 24$ S 7.

10. Shaw FE. HAV-tainted frozen strawberries top national news: Tale of the outbreak. Hepatitis Control Rep 1997;1-12.

11. Lowry PW, Levine R, Stroup DF, Gunn RA, Wilder MH, Konigsberg C Jr. Hepatitis A outbreak on a floating restaurant in Florida, 1986. Am J Epidemiol 1989;129:155-64.

12. Sobsey MD, Shields PA, Hauchman FS, Davis AL, Rullman VA, Bosch A. Survival and persistence of hepatitis A virus in environmental samples. In: AJ Zuckerman, ed. Viral Hepatitis and Liver Disease. New York: Alan R Liss Inc, 1988:121-4.

13. McCaustland KA, Bond WW, Bradley DW, Ebert JW, Maynard JE.
Survival of hepatitis A in feces after drying and storage for one month. J Clin Microbiol 1982;16:957-8.

14. Mbithi JN, Springthorpe VS, Boulet JR, Sattar SA. Survival of hepatitis A virus on human hands and its transfer on contact with animate and inanimate surfaces. J Clin Microbiol 1992;30:757-63.

15. Thraenhart $\mathrm{O}$. Measures for disinfection and control of viral hepatitis. In: Block SS, ed. Disinfection, Sterilization, and Preservation. Philadelphia: Lea \& Febiger, 1991:445-71.

16. Mbithi JN, Springthorpe VS, Sattar SA. Effect of relative humidity and air temperature on survival of hepatitis A virus on environmental surfaces. Appl Environ Microbiol 1991;57:1394-9.

17. Springthorpe VS, Sattar SA. Handwashing: product and technique comparisons. Infect Control Sterilization Tech 1996;2:19-22.

18. Bidawid S, Farber JM, Sattar SA. Survival of hepatitis A virus in food stored at modified atmosphere packaging environment. 66th Conjoint Meeting on Infectious Diseases. St John's, Newfoundland, October 25-29, 1999.

19. Raphael RA, Sattar SA, Springthorpe VS. Long-term survival of human rotavirus in raw and treated river water. Can J Microbiol 1985;31:124-8.

20. Bidawid S, Farber JM, Sattar SA. Contamination of foods by food handlers: Experiments on hepatitis A virus transfer and its interruption. Appl Environ Microbiol. (In press)

21. Parry JV, Mortimer PP. The heat sensitivity of hepatitis A virus determined by a simple tissue culture method. J Med Virol 1984;14:277-83.

22. Fleming B, Billing A, Vallbracht A, Botzenhart K. Inactivation of hepatitis A virus by heat and formaldehyde. Water Sci Tech 1985;17:43-5.

23. Millard J, Appleton H, Parry JV. Studies on heat inactivation of hepatitis A virus with special reference to shellfish. Part 1. Procedures for inactivation and recovery of virus from laboratory-maintained cockles. Part 2. Heat inactivation of hepatitis A virus in artificially contaminated cockles. Epidemiol Infect 1987;98:397-414.

24. Bidawid S, Farber JM, Sattar SA, Hayward S. Heat inactivation of hepatitis A virus (HAV) in dairy foods. J Food Prot 2000;63:522-8.

25. Bidawid S, Farber JM, Sattar SA. Inactivation of hepatitis A virus in fruits and vegetables by gamma irradiation. Int J Food Microbiol. (In press).

26. Sobsey M. Surface inactivation of hepatitis A virus on strawberries using chlorine. Annual Meeting of International Association of Milk, Food and Environmental Sanitarians. Nashville, Tennessee, August 16-19, 1998.

27. Mbithi JN, Springthorpe VS, Sattar SA. Chemical disinfection of hepatitis A virus on environmental surfaces. Appl Environ Microbiol 1990;56:3601-4

28. Sattar SA, Bidawid S. Environmental considerations in preventing the foodborne spread of hepatitis A. In: Hui YH, ed. Foodborne Disease Handbook, 2nd edn. New York: Marcel Dekker. (In press) 


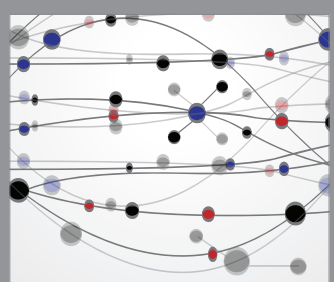

The Scientific World Journal
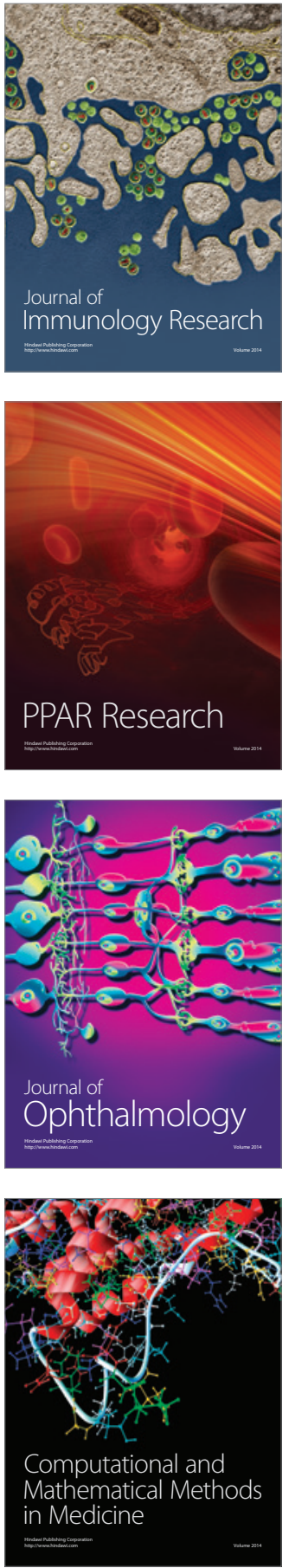

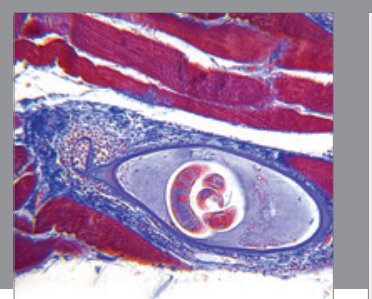

Gastroenterology Research and Practice

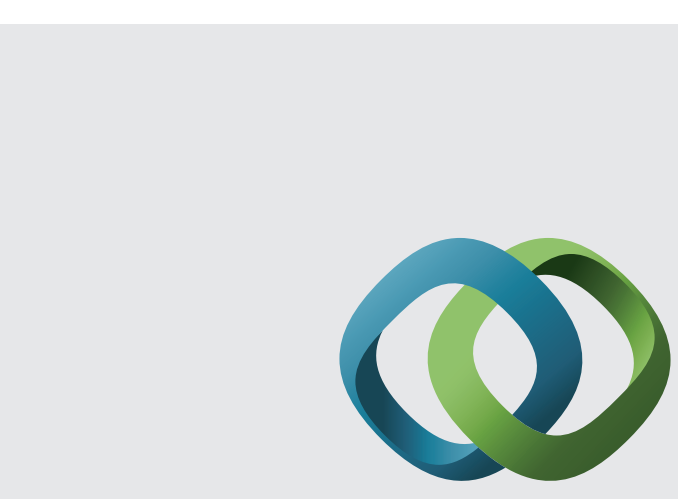

\section{Hindawi}

Submit your manuscripts at

http://www.hindawi.com
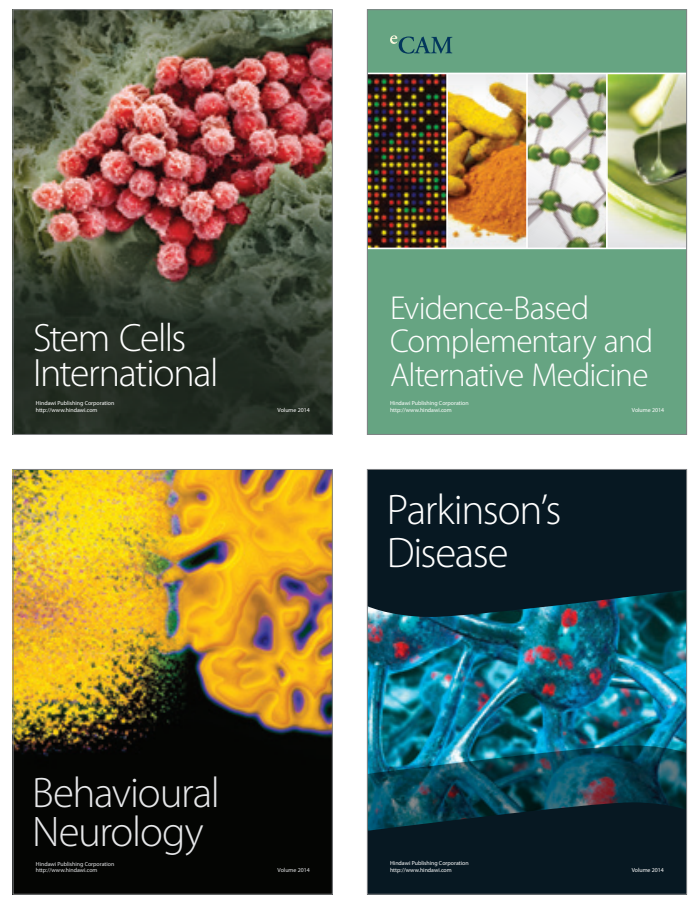
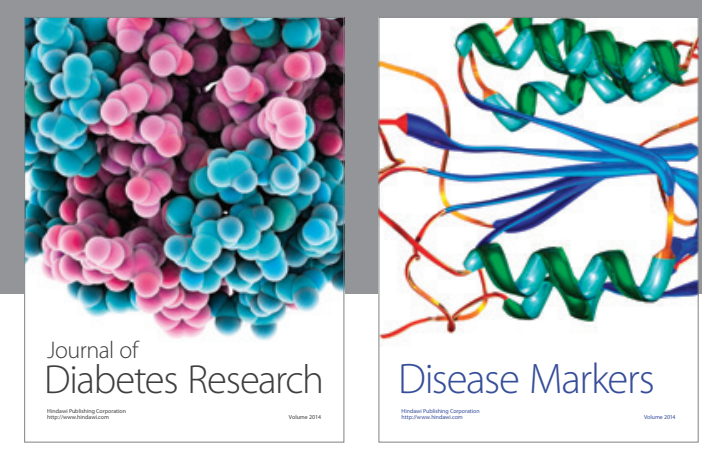

Disease Markers
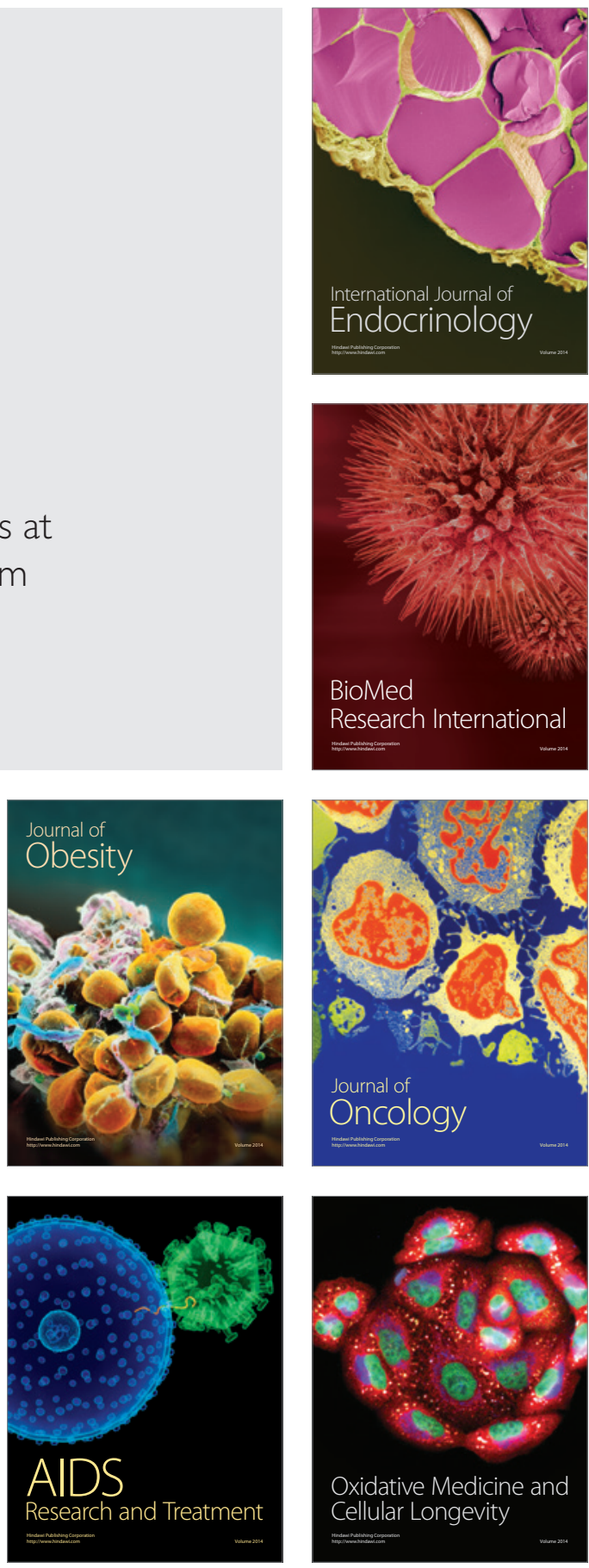